\title{
The lichen genus Pertusaria (Ascomycota) in Central Africa (Congo/Kivu, Rwanda and Burundi) and Western Kenya
}

\author{
by
}

\author{
Alan W. Archer ${ }^{1}$, John A. Elix ${ }^{2}$, Eberhard Fischer ${ }^{3}$, Dorothee Killmann ${ }^{3}$ and \\ Emmanuël Sérusiaux ${ }^{4}$ \\ ${ }^{1}$ National Herbarium of New South Wales, Mrs. Macquaries Road, Sydney, NSW 2000, \\ Australia, alanw.archer@bigpond.com \\ ${ }^{2}$ Department of Chemistry, Australian National University, Canberra ACT 0200, Australia, \\ John.Elix@anu.edu.au \\ ${ }^{3}$ Institute for Integrated Natural Sciences, Dep. of Biology, University of Koblenz-Landau, \\ Universitätsstraße 1, D-56070 Koblenz, Germany, efischer@uni-koblenz.de, \\ killmann@uni-koblenz.de \\ ${ }^{4}$ Plant Taxonomy and Conservation Biology, University of Liège, Sart Tilman B22, \\ B-4000 Liège, Belgium, E.Serusiaux@ulg.ac.be
}

With 9 figures

Archer, A.W., J.A. Elix, E. Fischer, D. Killmann \& E. Sérusiaux (2009): The lichen genus Pertusaria (Ascomycota) in Central Africa (Congo/Kivu, Rwanda and Burundi) and Western Kenya. - Nova Hedwigia 88: 309-333.

\begin{abstract}
The available collections of the lichen genus Pertusaria from the eastern parts of Central Africa (mainly in the Albertine Rift in Congo/Kivu, Burundi and Rwanda) and Western Kenya yielded 21 species. Four are described as new for science: Pertusaria fosseyae, P. kinigiensis, $P$. krogiae and P. lambinonii. The following species are new reports for Africa: $P$. commutata, P. maritima, $P$. melanostoma, $P$. mesotropa, $P$. microstoma, $P$. orarensis, $P$. pilosula, $P$. rigida, $P$. scaberula, $P$. subplanaica, $P$. subrigida, $P$. valliculata, and $P$. verruculifera. The following are reduced into synonymy: Pertusaria amboimensis with $P$. leioplacella, $P$. macrostomoides, $P$. prolifera and $P$. norstictica with $P$. endoxantha, $P$. kahuziensis with $P$. velata, and $P$. robsonii with $P$. limbata. $P$. aberdarensis is suspected to be a synonym of $P$. rigida. An identification key to all species is provided. The type collections of three further species described from Africa have been examined: $P$. kigomensis, $P$. regenerans and $P$. rhodesica.
\end{abstract}

Key words: New species, new reports, secondary chemistry.

\section{Introduction}

Pertusaria is generally poorly known in tropical Africa although there are many scattered records in the literature (Messuti et al. 2007). Here we report the results of 
our examination of the material available in the herbaria of the University of Koblenz (KOBL) and Liège (LG) and collected mainly in the Albertine Rift (Congo/Kivu, Rwanda and Burundi) and Western Kenya. We have also examined all type collections of the Pertusaria species described from Africa by Dodge (1964), deposited in FH. We have assessed their nomenclatural and taxonomic status. Further we provide a key for the identification of all species detected in this material.

The genus Pertusaria is cosmopolitan and shows a great deal of variation, especially in the secondary metabolites (lichen compounds) produced in the medulla. Many species have been recently described on the basis of subtle differences in morphology and chemistry. In this paper, we have refrained from introducing new names except when clear and well-supported variation can be circumscribed.

Recent molecular analysis of mtSSU and nuLSU sequences, using Minimum Evolution (ME) and Bayesian methods, demonstrates that the Pertusariaceae is a polyphyletic family as well as is the genus Pertusaria in its usual delimitation (Schmitt et al. 2006). Three well-supported clades include species currently assigned to the genus Pertusaria: (1) Pertusaria s. str. which is sister to the Coccotremataceae, (2) the Variolaria group (incl. species such as $P$. albescens, $P$. amara, and P. ophthalmiza), and (3) the Varicellaria group (incl. species such as $P$. hemisphaerica and $P$. velata). The clade including the Variolaria and the Varicellaria groups is sister to the genus Ochrolechia, but such a placement is considered as tentative for lack of strong support. The scope of this paper is not to study the monophyly of Pertusaria and we thus use the genus Pertusaria in its current, albeit artificial, delimitation.

\section{Materials and methods}

All material of Pertusaria from LG and KOBL was examined using standard light microscope technique and routine examination with water or $10 \% \mathrm{KOH}$ solution. All spores measurements refer to sections mounted in water. Chemical analysis were carried out using standard methods of thin layer chromatography (TLC, Orange et al. 2001) and gradient-elution high performance liquid chromatography (HPLC, Elix et al. 2003, Lumbsch 2002). Additional specimens were obtained from the following herbaria: BM, FH, G, HO, NSW, TUR.

\section{Results and discussion}

Pertusaria commutata Müll.Arg., Flora 67: 269. 1884.

Fig. 1, A-B

This species is readily characterized by its disciform apothecia, asci with a single, large ascospore and the production of haemathamnolic acid together with variable concentrations of lichexanthone. It is very similar to P. tropica Vain. (distinguished by the production of hypothamnolic acid) and to $P$. velata (Turner) Nyl. (distinguished by the production of lecanoric acid). Further details and discussion can be found in Archer (1997: 181-184).

A saxicolous population of $P$. commutata has been found on the summit of Mt. Bigugu (Rwanda, $2950 \mathrm{~m}$ ). Indeed, it is morphologically identical to the corticolous populations of $P$. commutata, although some larger ascospores have been observed 
(up to $225 \times 58 \mu \mathrm{m}$ ). A first sample has been examined by HPLC and contains haemathamnolic and protolichesterinic acids (major), decarboxyhaemathamnolic and lichesterininc acids (minor), and atranorin (minor); a second sample examined by TLC only produces haemathamnolic acid (major) and lichexanthone (minor). With the data available, we assign this population to $P$. commutata.

Pertusaria xantholeucoides Müll.Arg. (Nuovo Giorn Bot. Ital. 21: 357, 1889) is a saxicolous species described from Brazil and so far only known from the type material. Although the protologue includes description of ascospores, all five syntypes (G!) are sterile. They are very similar to $P$. commutata and contain haemathamnolic acid (major) and lichexanthone (minor). We first considered resurrecting this epithet for the saxicolous population from Mt. Bigugu, but we finally concluded that $P$. xantholeucoides is merely a synonym of $P$. commutata.

Pertusaria commutata is known from South America, the West Indies, south-eastern parts of the USA, southern China and Australia (Archer 1997). It is here reported as new for Africa. In the area of study, it is rather widespread and ubiquitous, being found on trees in savannahs as well as in montane forest (e. g. on bamboo culms); it also occurs in very disturbed areas and in plantations.

Selected SPECimens eXAmined: BuRundi. Kibezi, bordure de la forêt de montagne, M.Reekmans 4496 (LG). Région du Mosso, plaine de la Musindozi entre la plaine d'aviation de Gihofi et Mulamba, J.Lambinon 74/1381 (LG). Congo (RDC). Kivu, massif du Kahuzi, km 41 de la route BukavuWalikale, J.Lambinon 71/1167 (LG). RwandA. Parc National des Volcans, flanc SW du Bisoke, G.Troupin 14458 (LG). Karisoke Research Center, Hagenia-Hypericum Forest, Oct 2003, D.Killmann \& E.Fischer (KOBL). Nyungwe National Park, W Kitabi, Oct 2000, E.Fischer \& K.Kunsmann (KOBL). Ibid., Mt. Bigugu, summit, Oct 2003, E.Fischer (KOBL), ibid. Apr 2005, E.Sérusiaux (LG). Gisakura, Oct 2000, E.Fischer \& K.Kunsmann (KOBL).

Pertusaria endoxantha Vain., Hedwigia 37: 41. 1898. Fig. 1, C-D

TYPE: Kenya, ad corticem 6-8000 ped. s. m. prope Kikuyu, Scott-Elliot (TUR-Vain.-holotype!). = Pertusaria macrostomoides Dodge, Beih. Nova Hedwigia 12: 260. 1964.

TYPE: Kenya, Aberdare Mts., Kinangop Forest, section 4 south, on Juniperus procera, autumn 1958, Oliver Kerfoot (FH-holotype!).

= Pertusaria prolifera Dodge, Beih. Nova Hedwigia 12: 261. 1964.

TYPE: Kenya, Aberdare Mts., Kinangop Forest, section 4 south, on Juniperus procera, autumn 1958, Oliver Kerfoot (FH-holotype!).

= Pertusaria norstictica A.W.Archer, Mycotaxon 41: 232. 1991.

TyPE: Australia, Tasmania, Campania, $27 \mathrm{~km} \mathrm{~N}$ of Hobart, on Acacia mearnsii in open woodland, 22 Mar1981, G.Kantvilas 211/81 (HO-holotype!).

A detailed description of this species is provided by Archer (1997: 114, sub P. norstictica); it is characterized by its verruciform, sometimes confluent apothecia, with 1-3(-4) ostioles per verrucae, eight, uniseriate ascospores, 60-95 $\times 20-37 \mu \mathrm{m}$ and the production of norstictic acid.

Pertusaria endoxantha has been described from the area studied here but not close to the Ruwenzori range as the title of the paper may imply ["Lichenes a G.F.Scott- 

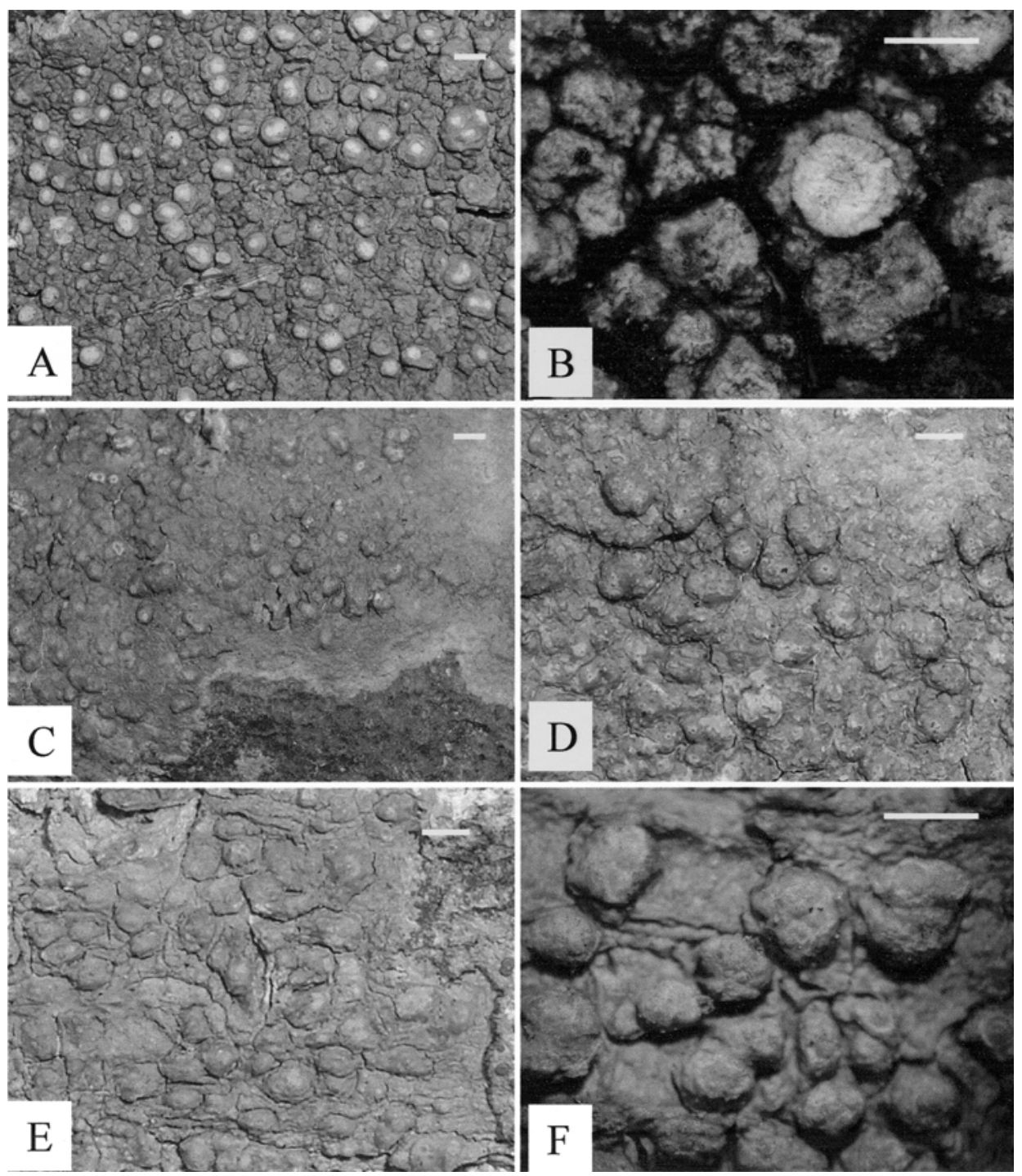

Fig. 1. A-B. Pertusaria commutata (A-B Fischer s.n., KOBL); C-D. Pertusaria endoxantha (Fischer s.n., KOBL); E-F. Pertusaria leioplacella (Fischer \& Kunsmann s.n., KOBL). Scale $=1 \mathrm{~mm}$.

Elliot in viciniis montis Ruwenzori $\left(0^{\circ} 5^{\prime}\right.$ l. s.) in Africa centrali annis $1893-94$ collecti"]. Indeed, the locality is said to be "ad corticem 6-8000 ped. s. m. prope Kikuyu", which is in Western Kenya, or in nearby Tanzania.

The types of Pertusaria macrostomoides and P. prolifera are parts of a single collection and, although the material of $P$. prolifera is better developed, the epithet 
macrostomoides is adopted here as it appears first in the original publication. The type of $P$. prolifera further produces connorstictic acid. P. norstictica, formerly recorded from Australia and Papua New Guinea (Archer 1997: 114-115), is reduced into synonymy as there is little doubt it belongs to the same species. The collection from Burundi (Reekmans 8495, LG) produces norstictic (major), connorstictic (minor) and 2'- $O$-methylstenosporic (minor) acids.

The rare $P$. undulata Müll. Arg., endemic to Australia, is very similar but produces 4,5-dichlorolichexanthone in addition to nortictic and connorstictic acids (Archer 1997: 160). Another species producing norstictic acid, P. sipmanii A.W.Archer \& Elix, endemic to Papua New Guinea, is easily distinguished by its biseriate, larger ascospores [180-210 × (40-)50-62 $\mu \mathrm{m}]$ (Archer \& Elix 1998a: 170-171).

In Africa, the species is reported from Kenya (Aberdare Mts.), Rwanda and Burundi, where it grows on trees, in montane and dry forests at mid elevation. P. macrostomoides is most probably a paleotropical species.

Additional specimens examined: Burundi. Prov. Muramvya, Teza, forêt de montagne, sur Ficus, 2100 m, Dec 1979, M.Reekmans 8495 (LG). Rwanda. Akagera National Park, dry forest SW Lake Ihema, on Haplocoelum gallaense, 1300 m, Oct 2003, E.Fischer (KOBL, LG).

Pertusaria fosseyae A.W.Archer, Elix, Eb. Fisch., Killmann \& Sérus. sp. nov.

Fig. 2

Mycobank no. MB 513256

Pertusariae balekenses similis sed lichexanthone continens vice 4,5-dichlorolichexanthone differt.

Type: Congo (RDC), Kivu, massif du Kahuzi, piste du Kahuzi, sur le versant SW du mont, forêt clairesemée à Agauria salicifolia, base de l'étage des bruyères, sur tronc d'Agauria, 2760 m, Dec 1971, J. Lambinon 71/1229 (LG-holotype).

Thallus corticolous, pale greenish grey to grey, surface slightly cracked and typically shiny, with numerous greyish white, rounded soralia, separate at but eventually partly confluent and rarely invading the thallus surface, raised and usually marginate, $0.5-1 \mathrm{~mm}$ in diam. Apothecia present or absent, verruciform to subglobose but usually with a depressed, complanate upper part, $0.6-1 \mathrm{~mm}$ in diam., usually with a constricted base, sometimes emerging from soralia or laterally covered by soralia, usually confluent and forming large, areolate verrucae with 2-6 ostioles, ostioles depressed, not clearly delimited, typically bluish grey to blackish. Ascospores eight per ascus, biseriate, ellipsoid, 98-111 × 30-35 $\mu \mathrm{m}$, including a 3-5 $\mu \mathrm{m}$ thick wall, inner wall minutely rugose.

Chemistry (determined by TLC and HPLC): stictic acid (major), constictic acid (minor), lichexanthone (major) and norlichexanthone (trace).

The species is named in honour of the world famous zoologist Dr. Diane Fossey (1932-1985) who worked at Karisoke Research Station (Rwanda) for the protection of the mountain gorillas (Gorilla beringei) and their environment.

Pertusaria fosseyae is characterized by the grey-green, shiny thallus with numerous greyish-white soralia and the presence of lichexanthone and stictic acid. It closely resembles P. balekensis A.W.Archer \& Elix from Papua New Guinea (Archer \& 

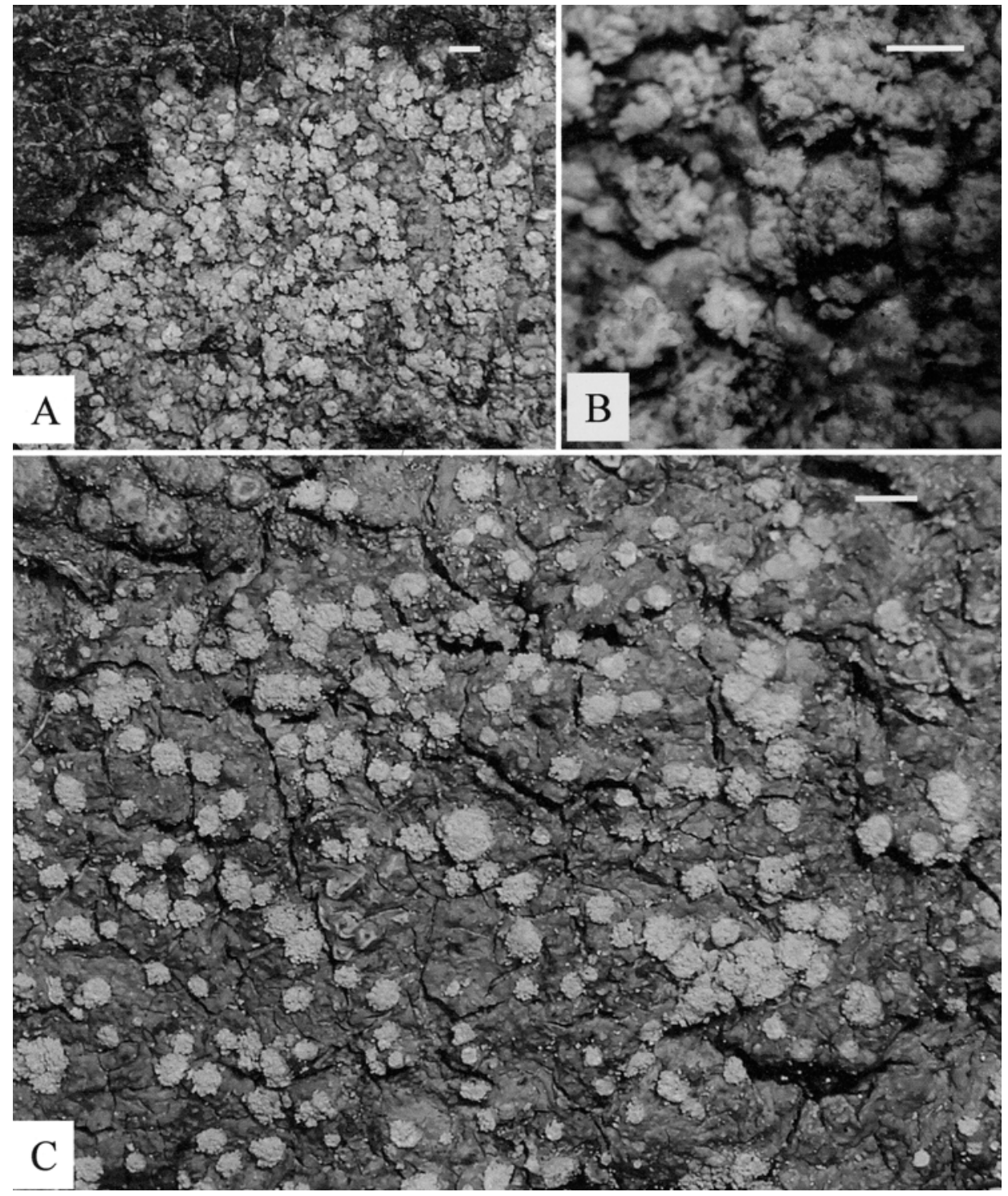

Fig. 2. A-C. Pertusaria fosseyae (A, C holotype, LG, B Killmann \& Fischer s.n., LG). Scale = 1 mm.

Elix 1998a), and P. puffina A.W.Archer \& Elix from Australia and Papua New Guinea (Archer 1997), but those species contain 4,5-dichlorolichexanthone in the former, and 2,4- and 2,5-dichlorolichexanthone in the latter, rather than lichexanthone present in $P$. fosseyae. Moreover, apothecia are unknown in $P$. balekensis and P. puffina. 
Pertusaria dehiscens Müll.Arg. has similar apothecia and ascospores, and also produces stictic acid and lichexanthone as major compounds but is easily differentiated by the absence of soralia. It is known from Brazil, India and Australia (Archer 1997: 55-57).

Pertusaria fosseyae is a rare, corticolous species in montane forests, known only from the Kahuzi and the Virunga mountain ranges in the Albertine Rift.

Additional SPecimen eXAmined: Rwanda. Volcano National Park, Karisoke Research Center, Oct 2003, D.Killmann \& E.Fischer (LG).

Pertusaria kinigiensis A.W.Archer, Elix, Eb. Fisch., Killmann \& Sérus. sp. nov. Fig. 3

Mycobank no. MB 513257

Pertusariae morelienses similis sed lichexanthonum deficiens differt.

Type: Rwanda, Chaîne des Birunga, Kinigi (NW de Ruhengeri), 2250 m, blocs de lave dans un pâturage, 2250 m, Feb 1972, J. Lambinon 72/421 (LG-holotype).

Thallus saxicolous, pale grey to pale yellowish grey, rather thick, the upper surface subtuberculate and dull; soralia numerous and conspicuous, circular but poorly delimited, white to yellowish, 0.5-1 mm diam., usually with coarse soredia. Apothecia unknown.

CHEMISTRY (determined by TLC): haemathamnolic acid.

The species is named after the type locality at Kinigi in NW Rwanda, near the Volcanoes National Park where the mountain gorilla survives through the dedicated protection of local populations.

Pertusaria kinigiensis is a saxicolous, sorediate species producing haemathamnolic acid. It is similar to P. moreliensis B. de Lesd., a Neotropical saxicolous species found in central Mexico northwards to SW U.S.A. and the West Indies (Lumbsch et al. 1999: 228-229, Lumbsch \& Nash 2002), and which differs in containing additional lichexanthone. All collections from Africa produce only haemathamnolic acid; however, one collection, examined by HPLC (Rugarama, E.Sérusiaux , LG) produces additional protolichesterinic acid (major), decarboxyhaemathamnolic and lichesterinic acids (minor). The same major compounds have also been found in a saxicolous collection referred to $P$. commutata (see above).

Pertusaria kinigiensis has been found on rocks in open conditions between 1600 and $2250 \mathrm{~m}$ elevation in Rwanda and Burundi. It may be widespread in Africa as further collections are known from rocks in Zimbabwe (fide Uwe Becker, pers. comm.).

AdDitional SPECIMENS EXAMINED: BuRundi. Munini-Kumuyange (20 km S-E de Bururi), J.Lambinon 74/1326 (LG). Rwanda. Rive N du lac Bulera (NE de Ruhengeri), J.Lambinon 72/749(LG). Nyungwe National Park, Karamba, along old road to Ntendezi, Oct 2003, D.Killmann \& E.Fischer (KOBL). near Rugarama, Oct 2003 and Apr 2005, D.Killmann \& E.Fischer (KOBL), ibid. Apr 2005 E.Sérusiaux (LG). 

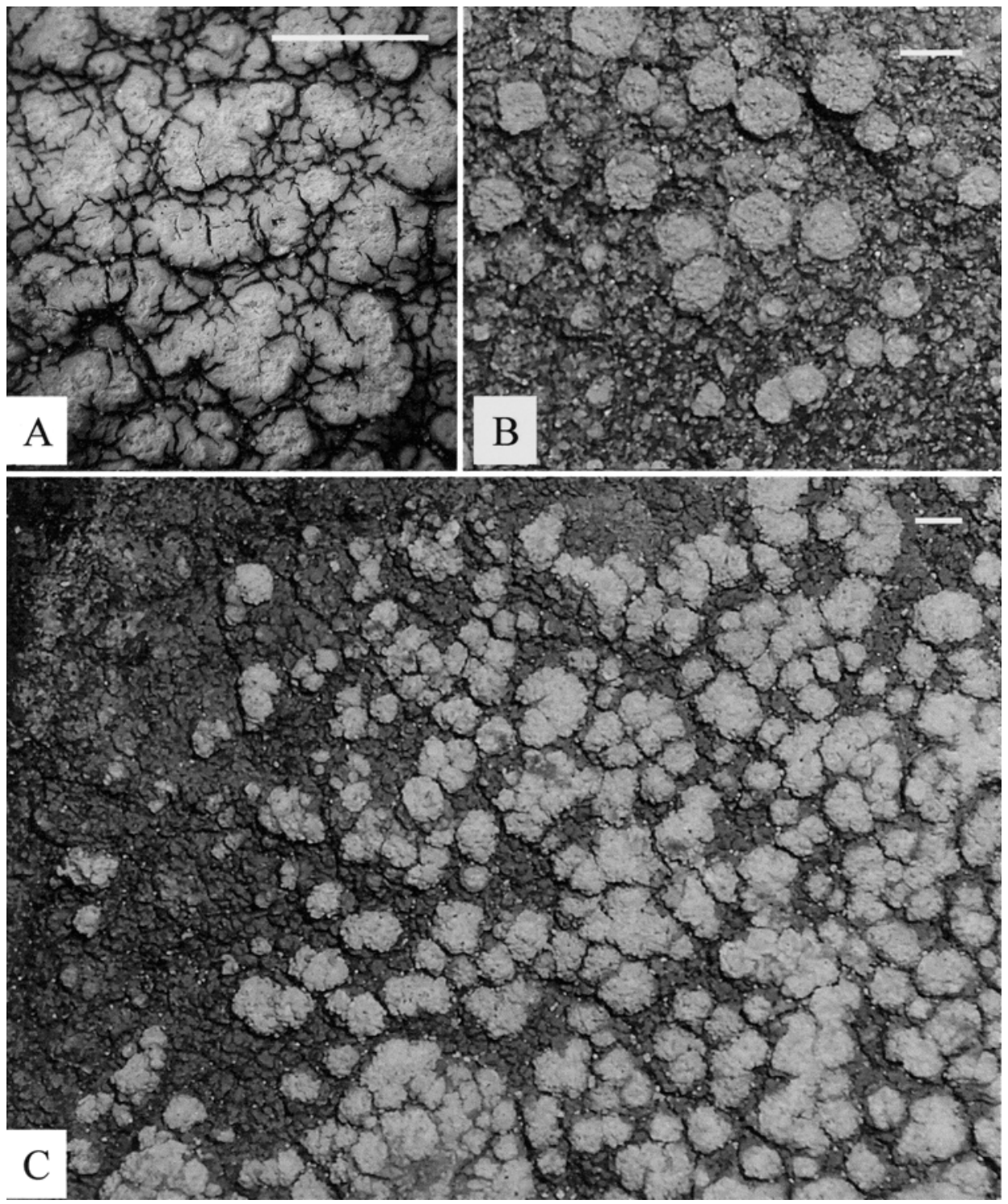

Fig. 3. A-C. Pertusaria kinigiensis (A-B. Lambinon 74/1326, LG, B. Killmann \& Fischer s.n., KOBL, C. holotype, LG). Scale $=1 \mathrm{~mm}$.

Pertusaria krogiae A.W.Archer, Elix, Eb. Fisch., Killmann \& Sérus. sp. nov. Fig. 4 Mycobank no. MB 513258

Differt ab omnibus speciebus generis Pertusariae presentia acidi lichesterinici et acidi alloprotolichesterinici. 

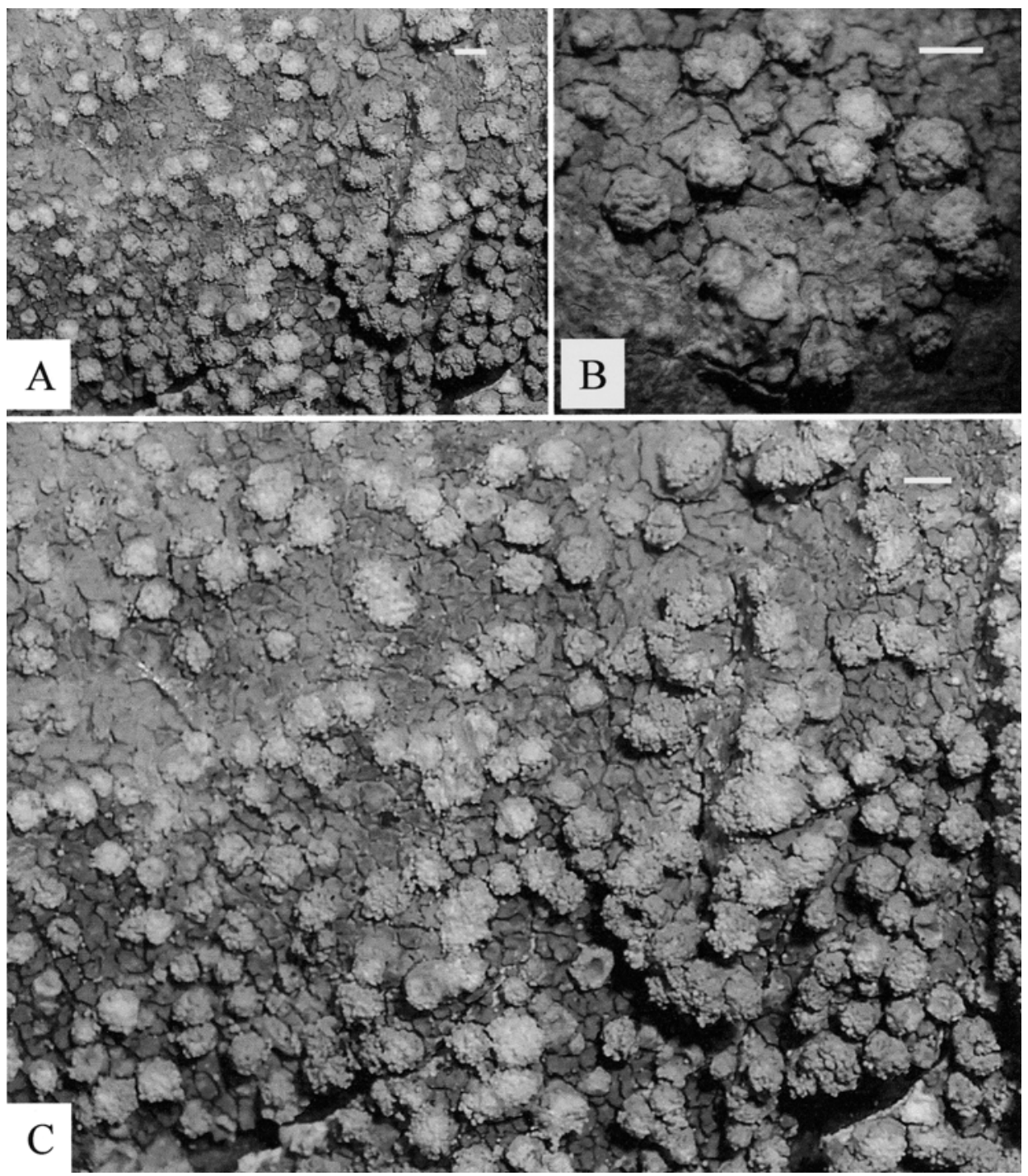

Fig. 4. A-C. Pertusaria krogiae (holotype, LG). Scale $=1 \mathrm{~mm}$.

TyPe: Rwanda, Parc National de l'Akagera, dry forest SW Lake Ihema, on Haplocoelum gallaense, 1370 m, Oct 2003, E. Fischer (LG-holotype).

Thallus corticolous, pale grey to greenish grey, surface verrucose or irregularly cracked, with numerous greyish white soralia, marginate, $0.2-1.2 \mathrm{~mm}$ in diameter, sometimes confluent, typically raised or subtuberculate (up to $0.5 \mathrm{~mm}$ high). Apothecia unknown. 
Chemistry (holotype, determined by HPLC): lichesterinic acid (major), alloprotolichesterinic acid (minor) and atranorin (trace).

The species is dedicated to Hildur Krog (Oslo) who collected numerous lichens in East Africa and published the first comprehensive flora of macrolichens in Africa, together with T.D.V.Swinscow (Swinscow \& Krog 1988).

Pertusaria krogiae is characterized by the grey thallus with numerous greyish white, raised to subtuberculate soralia and the presence of protolichesterinic (major or absent), lichesterinic (major or minor), allo-protolichesterinic (minor or absent) acids and atranorin (minor or absent). It is another sterile sorediate species characterized by its chemistry. P. tropica may contain lichesterinic acid, protolichesterinic acid, isonephrosterinic acid, and nephrosterinic acid as well as the thamnolic acid chemosyndrome. P. albescens from North America contains only fatty acids allopertusaric and dihydropertusaric acids which are closely related to the lichesterinic acids.

Pertusaria krogiae is a corticolous species found in primary rather dry forests in Western Kenya and Rwanda, as well as in cultivated parks.

Additional SPeCimens EXamined: KenYa. Kakamega Forest, Ikuywa, Oct 2003, D. Killmann \& E.Fischer (KOBL). Rwanda. Same locality as type, 1400 m, Oct 2003, E.Fischer (LG). Butare, IRST park, Mar 2005, E.Sérusiaux (LG).

Pertusaria lambinonii A.W.Archer, Elix, Eb. Fisch., Killmann \& Sérus. sp. nov. Fig. 5

Mycobank no. MB 513259

Pertusariae parnassiae et Pertusariae anomalosporae affinis, sed presentia acidi planaici, acidi 2'-O-methylperlatolici, acidi protocetrarici acid et lichexanthoni differt.

TYPE: Congo (RDC), Kivu, Massif du Kahuzi, piste du Kahuzi, versant SW du Mt. Kahuzi, rochers éclairés, type porphyre, 2840 m, Dec 1971, J.Lambinon 71/1291 (LG-holotype; NSW-isotype).

Thallus saxicolous or corticolous, pale olive-green to greenish grey, thick, surface subtuberculate, cracked and dull. Isidia and soredia absent. Apothecia verruciform, rather flattened, conspicuous, numerous, sometimes crowded, rarely confluent, concolorous with the thallus, surface $+/$ - smooth or irregularly undulate, (1-) $1.5-2 \mathrm{~mm}$ diam., ostioles inconspicuous, black, punctiform, 1(-2) per verruca. Hamathecium and asci of the Pertusaria-type. Ascospores eight per ascus, uniseriate, rounded ellipsoid, rough-walled (inner wall with distinct transverse ridges, sometimes anastomosing), 80-125 × 34-42 $\mu \mathrm{m}$.

Chemistry (determined by TLC and HPLC): planaic acid (major), 2'- $O$-methylperlatolic acid (major), protocetraric acid (major) and lichexanthone (minor).

The species is named in honour of Jacques Lambinon (Liège) who made his extensive lichen collections from the Albertine Rift available for this study.

Only two other species have eight, rough-walled ascospores (for more details on this type of spore see Dibben 1980: 10-12): P. parnassia Vain., described and so far only know from Guadeloupe (West Indies), and P. anomalospora A.W.Archer, Elix \& Streimann from Papua New Guinea (Archer et al. 1995: 388). The chemistry 

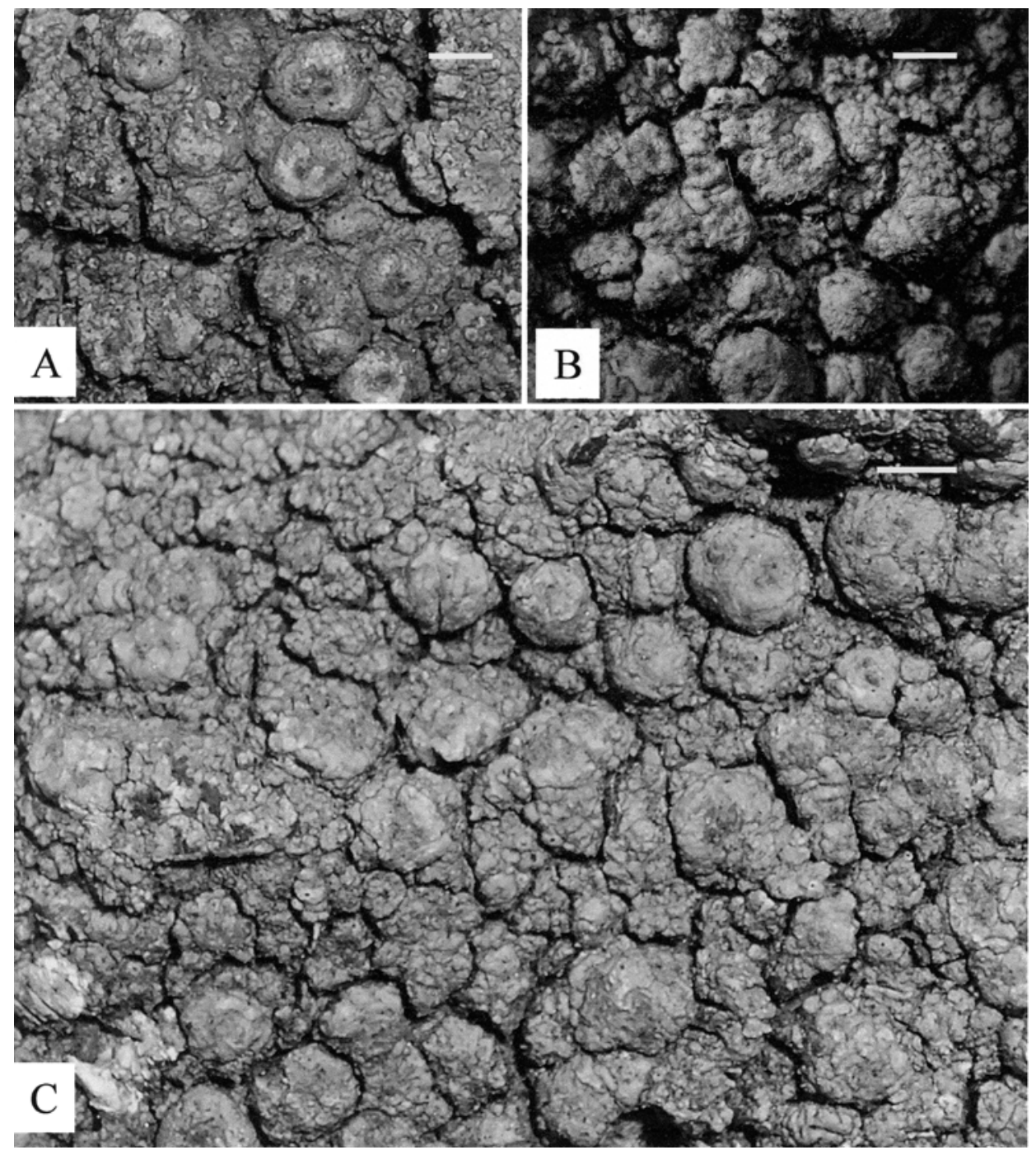

Fig. 5. A-C. Pertusaria lambinonii (holotype, LG). Scale $=1 \mathrm{~mm}$.

is diagnostic: $P$. parnassia contains lichexanthone and stictic acid while $P$. anomalospora contains 2,5-dichlorolichexanthone (major), 4,5-dichlorolichexanthone (major), 2,4-dichlorolichexanthone (minor) and 2-chlorolichexanthone (trace).

Pertusaria lambinonii grows on rocks and on Erica trunks in exposed situations (2400-2840 m) within primary vegetation in the Albertine Rift.

Additional specimens eXamined: Burundi. Mt. Manga (crête Congo-Nil), versant SE, J.Lambinon 74/1206 (LG). Rwanda. Nyungwe National Park, below the summit of Mt. Bigugu, Apr 2005, E.Sérusiaux (LG). 
Pertusaria leioplacella Nyl., Bull. Soc. Linn. Normandie, sér. 2, 2: 271.1867.

Fig. 1, E-F

= Pertusaria amboimensis Dodge, Beih. Nova Hedwigia 12: 255. 1964.

TyPE: Angola, Cuanza Sul, 1000 m, on dead tree, 5 Feb 1933, Gossweiler 9991 (FH-holotype !).

Pertusaria leioplacella is a corticolous species with a yellowish-grey thallus typically $\mathrm{KC}+$ yellow-orange, with numerous verruciform apothecia with 1-4 ostioles per verrucae, and eight uniseriate smooth ascospores. The chemistry of the African collections includes thiophaninic acid (sometimes only in trace) and stictic acid (major) together with constictic and hypostictic acids, and sometimes 2-chloro-6-Omethylnorlichexanthone.

The type collection of Pertusaria amboimensis Dodge (1964: 255) has been examined. The asci contain eight uniseriate spores (not two as stated in the original description) and contains thiophaninic acid (major), stitic acid (major), constictic acid (minor) and hypostictic acid (minor). P. amboimensis can thus be confidently reduced to synonymy with $P$. leioplacella.

Pertusaria leioplacella is a widely distributed tropical to subtropical species in the Southern Hemisphere (Argentina, Australia, Brazil, New Caledonia, Paraguay, South Africa, Uruguay, Vanuatu) and in Cuba, Hawaii, Mexico and the West Indies (Archer 1997). It is reported here from tropical Africa for the first time, where it is quite rare and occurs at mid elevations, in subprimary forests and cultivated areas.

AdDitional SPECimENS EXAmined: KenYa. Kakamega Forest, near Udos Bandas, Oct 2001, D.Killmann $\&$ E.Fischer (KOBL). RwANDA. Butare, agroforestry fields of the PASI project, Oct 2000, E.Fischer \& K.Kunsmann (KOBL).

Pertusaria maritima A.W.Archer \& Elix, Telopea 6: 19. 1994.

Fig. 6, A

The African collections of Pertusaria maritima are corticolous, sorediate (young soralia slightly immersed, marginate) and produce thiophaninic acid only (determined by TLC). It is known from coastal and low elevations areas in Australia (Archer 1997: 100-101), where it also produces stictic (minor) and constictic (trace) acids, as well as norlichexanthones (minor or trace).

Pertusaria maritima is reported here as new for Africa, although this identification is tentative because of differences in the chemistry; indeed, further studies may demonstrate that a different species must be recognized for the African collections. It was found only in the Virunga Range, at 990 and 2300 m elevation

Specimens examined: Congo (RDC). Kivu, Parc National des Virunga, sur la piste de Lulimbi, J.Lambinon 72/609 (LG). Rwanda. Chaîne des Virunga, Kinigi (NW de Ruhengeri), plantation Rops, J.Lambinon 72/738 (LG).

Pertusaria melanostoma Krempelh., Flora 61: 517. 1878.

Fig. 6, B

The African collections here referred to P. melanostoma are corticolous, with verruciform apothecia, pale or black (in a single collection: Bisoke, Oct 2003, D.Killmann , KOBL) ostioles, 1-3 per verrucae, eight, uniseriate, slightly rough ascospores $75-90 \times 28-40 \mu \mathrm{m}$, and produce stictic acid (major), constictic, cryptostictic 
and peristictic acids (minor or trace), 4,5-dichlorolichexanthone (minor), and 4-chlorolichexanthone (trace). They are tentatively assigned to P. melanostoma, which has dark ostioles and ascospores reported to measure 48-72 × 19-30 $\mu \mathrm{m}$; unfortunately, examination of the type material yielded no mature ascospores. It contains 4,5-dichlorolichexanthone (submajor), stictic acid (major) and constictic acid (minor). Further study is required to obtain a definitive description of this species.

Pertusaria melanostoma is a corticolous species of the montane forest, and artificial habitats at the same elevation. It was previously reported only from Argentina and is here reported as new for Africa.

AdDitional SPECimEnS EXAMinED: KenYa. Mt. Kenya, montane forest, Oct 2002, D.Killmann (KOBL). Rwanda. Versant droit de la vallée de la Sebeya, J.Lambinon 74/633 (LG). Volcano National Park, at the foot of Bisoke, Mar 2003, D.Killmann (KOBL). Nyungwe National Park, Gisakura, Oct 2000, E.Fischer \& D.Killmann (KOBL).

Pertusaria mesotropa Müll.Arg., Flora 67: 350. 1884.

Fig. 6, C-D

Pertusaria mesotropa is distinguished by its verrucae containing 1-3(5) apothecia, each usually with a distinct ostiole, asci with 8 , uni- or biseriate ascospores, 85-105 $\times 32-40 \mu \mathrm{m}$ (measurements from J.Lambinon 72/445), and the production of 2'-Omethylperlatolic and 4,5-dichlorolichexanthone. A detailed description is available in Lumbsch et al. (1999: 223-228). The populations found in Africa differ somewhat in their low concentrations or complete absence of 4,5-dichlorolichexanthone; both chemotypes (with or without the xanthone) occur together (J.Lambinon 74/444 \& 445, LG).

The recently described $P$. phulhuangensis (Jariangprasert 2006) from Thailand is closely related, and differs in lacking 4,5-dichlorolichexanthone but containing additional stictic acid.

Pertusaria mesotropa has been reported previously from Sri Lanka (type collection) and NW Mexico (Lumbsch et al. 1999: 228). It is new to Africa where it was found in the Virunga volcanoes range, in the montane forest at 2200-2550 m elevation and at lower altitude in the xerophilous forest colonizing recent lava flows.

SPECIMENS EXAMINED: CONGO (RDC). Kivu, plaine de lave du Nyamuragira à l'ESE de Sake, J.Lambinon $72 / 567$ (LG). Kenya. Mt. Kenya, montane rainforest near Chogoria Park Gate, 10. Oct 2002, D.Killmann (KOBL). RwandA. W du poste minier de Gikungu, J.Lambinon 74/633 (LG). Parc National des Volcans, versant S du Sabyinyo, J.Lambinon 72/444 \& 445 (LG).

Pertusaria microstoma Müll.Arg., Flora 65: 328. 1884.

Fig. 6, E-F

A single saxicolous collection was tentatively identified as Pertusaria microstoma. It has a pale grey thallus, with numerous hemispherical verrucae with pale brown ostioles, and asci with four, rough-walled ascospores, 100-120 × 34-42 $\mu \mathrm{m}$. It produces (determined by TLC and HPLC) 2'-O-methylperlatolic acid (major), confluentic acid (minor) and 4,5-dichlorolichexanthone (trace).

No saxicolous Pertusaria species with four rough-walled ascospores are known but several corticolous taxa with such ascospores have been recorded (Archer et al. 1995, Archer 1997). Amongst them, P. microstoma (Archer 1997: 107-108) also produces 

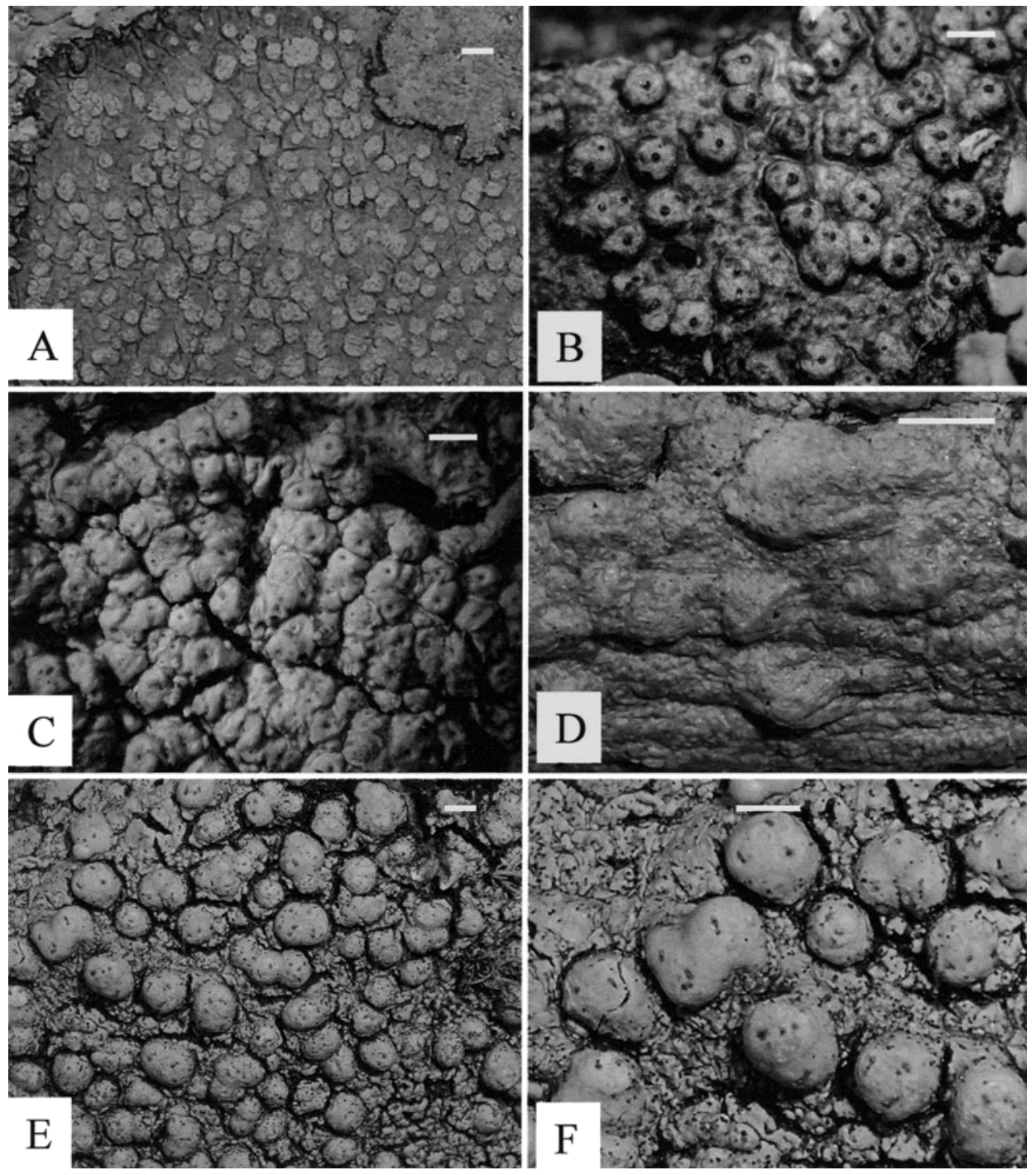

Fig. 6. A. Pertusaria maritima (Lambinon 72/609, LG); B. Pertusaria melanostoma (Killmann s.n., KOBL); C-D. Pertusaria mesotropa (C. Lambinon 72/445, LG, D. Killmann s.n., KOBL); E-F. Pertusaria microstoma (Lambinon 74/1335, LG). Scale $=1 \mathrm{~mm}$.

2'-O-methylperlatolic acid (major) and 4,5-dichlorolichexanthon, but differs by containing additional minor or trace amounts of stictic, constictic and planaic acids.

Pertusaria microstoma is known from Indonesia/Java, Papua New Guinea, Australia and New Caledonia (Archer 1997). It is thus new for Africa where the single collection was found on rocks inside a riverine forest at $1900 \mathrm{~m}$ elevation. 
Specimen examined: Burundi. Munini-Kumuyange (20 km S-E de Bururi), petite galerie forestière des sources de la Siguvyaye, J.Lambinon 74/1335 (LG).

Pertusaria orarensis A.W.Archer \& Elix, Bibl. Lichenol. 69: 117. 1997.

Fig. 7, A-B

Pertusaria orarensis has verruciform apothecia with a single central ostiole, eight biseriate ascospores, and contains divaricatic acid and 2-chlorolichexanthone as major lichen compounds. The African specimen contains additional traces of methyl 2,2'di- $O$-methyldivaricate (also mentioned in the original description), methyl-2- $O$ methyldivaricate and stenosporic acid. A detailed description is available in Archer \& Elix (1997: 117).

Pertusaria orarensis occurs in Australia/New South Wales and Papua New Guinea (Archer 1997; Archer \& Elix 1998b) and is thus new to Africa. A single population has been found on tiny branches (collected on the ground) at the edge of a primary montane forest at $2180 \mathrm{~m}$ in the Kahuzi range.

SPECIMEN EXAminED: Congo (RDC). Kivu. Massif du Kahuzi, en bordure du marais Musisi, J.Lambinon 71/1143b (LG).

Pertusaria pilosula A.W.Archer \& Elix, Bibl. Lichenol. 69: 127. 1997.

Fig. 7, C-D

Pertusaria pilosula (Archer 1977: 127-128) is a sterile, isidiate, Australian species which contains 2'-O-methylperlatolic acid (major), 4,5-dichlorolichexanthone (minor), stictic (major) and constictic acids (minor). The African collections reported here produce the first two compounds but the stictic acid chemosyndrome.

Other populations of corticolous, very similar, sterile and isidiate Pertusaria have been given taxonomic rank on the basis of their chemistry: P. buburana Elix \& Archer from Papua New Guinea (Elix et al. 1997) which contains only 2'-Omethylperlatolic acid, and $P$. pilosula var. abditiva from Thailand (Jariangprasert 2006) which contains 2 '- $O$-methylperlatolic, stictic and constictic acids. The Australian species $P$. georgeana A.W.Archer \& Elix (Archer 1997: 68) that contains the isomeric 2-O-methylperlatolic acid together with the same xanthone is also closely related.

At present Pertusaria pilosula is only known from Australia/New South Wales and is thus new for Africa, even though some doubt remains about the genuine identity of the collections reported. In Africa, it appears to be a rare corticolous species in montane forests.

SPeCimens examined: Congo (RDC). Kivu, massif du Kahuzi, piste du Kahuzi, J.Lambinon 71/1227 (LG). Rwanda. Nyungwe National Park, Uwinka, Sep 1999, E.Fischer (KOBL).

Pertusaria rigida Müll.Arg., J. Linn. Soc. (Bot.) 29: 221. 1893).

Fig. 7, E-F

?=Pertusaria aberdarensis Dodge, Beih. Nova Hedwigia 12: 254. 1964.

TYPE: Kenya, Aberdare Mts., Kinangop Forest, sect. 4 south, on twig of Juniperus procera, autumn 1958, Oliver Kerfoot (FH-holotype!). 

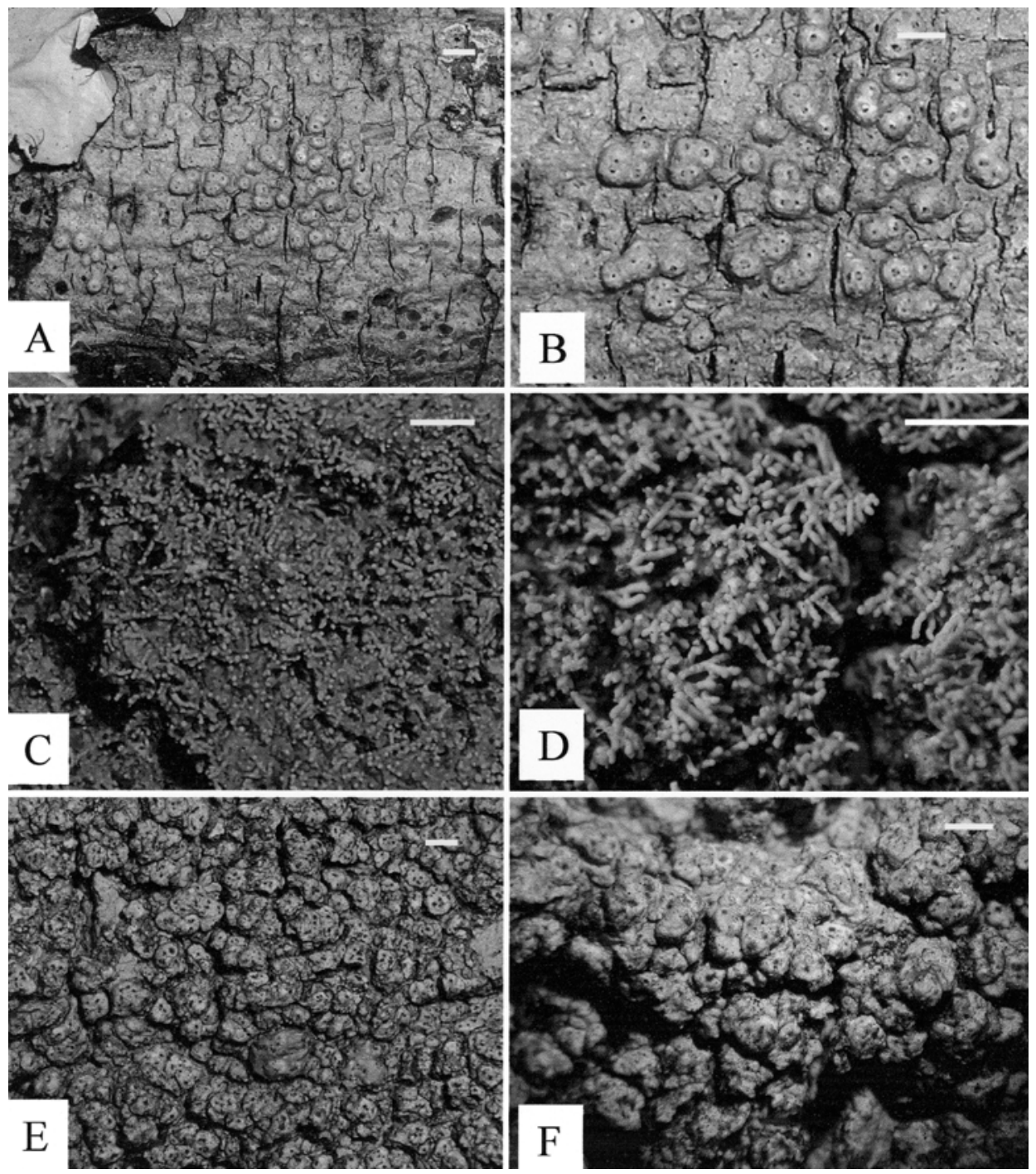

Fig. 7. A-B. Pertusaria orarensis (Lambinon 71/1143bis, LG); C-D. Pertusaria pilosula (Lambinon 71/1227, LG); E-F. Pertusaria rigida (Killmann s.n., KOBL). Scale $=1 \mathrm{~mm}$.

Pertusaria rigida is a fertile species (apothecia verruciform, subhemispherical or rather flattened, scattered or numerous, confluent, concolorous with the thallus, $0.8-2 \mathrm{~mm}$ diam., ostioles dark, 6-10 per verrucae) characterized by asci with 8 and the presence of 4.5-dichlorolichexanthone; additional 4,5-dichloro-6-Omethyl-norlichexanthone (minor) and atranorin (major) have been detected in several collections. The presence of 4.5-dichlorolichexanthone distinguishes the 
species from the similar $P$. subrigida, which lacks lichen compounds (see under that species).

The type material of Pertusaria aberdarensis is very scanty but the prescence of 4,5-dichlorolichexanthone was confirmed by HPLC. The thallus is smooth, and verrucae have 1-2 apothecia, each with a single ostiole. No section has been made to check the ascospores (said to be 4 per ascus but with "usually only 3 mature" in the original description), and thus the synonymy with $P$. rigida is tentative.

Pertusaria rigida occurs in India and Australia (Queensland and New South Wales, Archer 1997). This is the first report for Africa where it was found in Rwanda (in montane forest or in plantations at the same elevation) and Kenya (in the semideciduous tropical forest of Kakamega).

AdDitional SPECIMENS EXAMINED: KenYa. Kakamega Forest, near Udos Bandas, Oct 2001, D.Killmann \& E.Fischer (KOBL). Rwanda. Volcano National Park (border of the park), at foot of Bisoke, Mar 2003, D.Killmann (KOBL). Karisoke, Oct 2003, E.Fischer (KOBL). Nyungwe National Park, Mt. Bigugu, Apr 2005, E.Sérusiaux (LG).

Pertusaria scaberula A.W.Archer, Mycotaxon 41: 240. 1991.

Fig. 8, A

Pertusaria scaberula is a corticolous species characterized by disciform apothecia and slighty raised soralia and the production of thamnolic acid with or without lichexanthone (Archer 1997: 200). All African collections contain only thamnolic acid.

Pertusaria scaberula is known from Australia, Papua New Guinea and Norfolk Island (Archer 1997) and is reported here as new to Africa. It was detected only in the Albertine Rift at medium elevations, in disturbed or cultivated areas.

Specimens eXamined: Congo (RDC). Kivu, Parc National des Virunga, Mabenga, J.Lambinon 72/ 646 (LG). RwANDA. Butare, agroforestry fields of the PASI project, Oct 2000, E.Fischer \& K.Kunsmann (KOBL). Parc National de la Forêt de Nyungwe, Gisakura tea factory, Oct 2000, E.Fischer \& K.Kunsmann (KOBL).

Pertusaria subplanaica A.W.Archer \& Elix, Mycotaxon 45: 422. 1992.

Fig. 8, B-D

Pertusaria subplanaica is a corticolous species characterized by verruciform apothecia, eight uniseriate ascospores, and the production of 2,2'-di- $O$-methylstenosporic. Traces of methyl-2,2'-di- $O$-methylstenosporate, 4,5-dichlorolichexanthone, 2,2'-di- $O$ methyldivaricatic and 2'-O-methylstenosporic acids were detected in the African collections. A detailed description is available in Archer \& Elix (1992:423) \& Archer (1997: 144-146).

Pertusaria subplanaica was formerly known from Australia (Queensland and New South Wales), New Zealand and Papua New Guinea (Archer 1997). It is new for Africa and has been found on bark in montane forest up to $3000 \mathrm{~m}$ on Mt. Kenya.

Specimens examined: Congo (RDC). Kivu, massif du Kahuzi, piste du Kahuzi, versant SW du Mt. Kahuzi, J.Lambinon 71/1228 (LG). KenYa. Mt. Kenya, Chogoria gate, Sep 2002, D.Killmann \& E.Fischer (KOBL) Ibid., Chogoria gate, Sep 2002, D.Killmann \& E.Fischer (KOBL). Rwanda. Parc National de la forêt de Nyungwe, crête du Mt. Muzimu, J.Lambinon 72/943A (LG). 

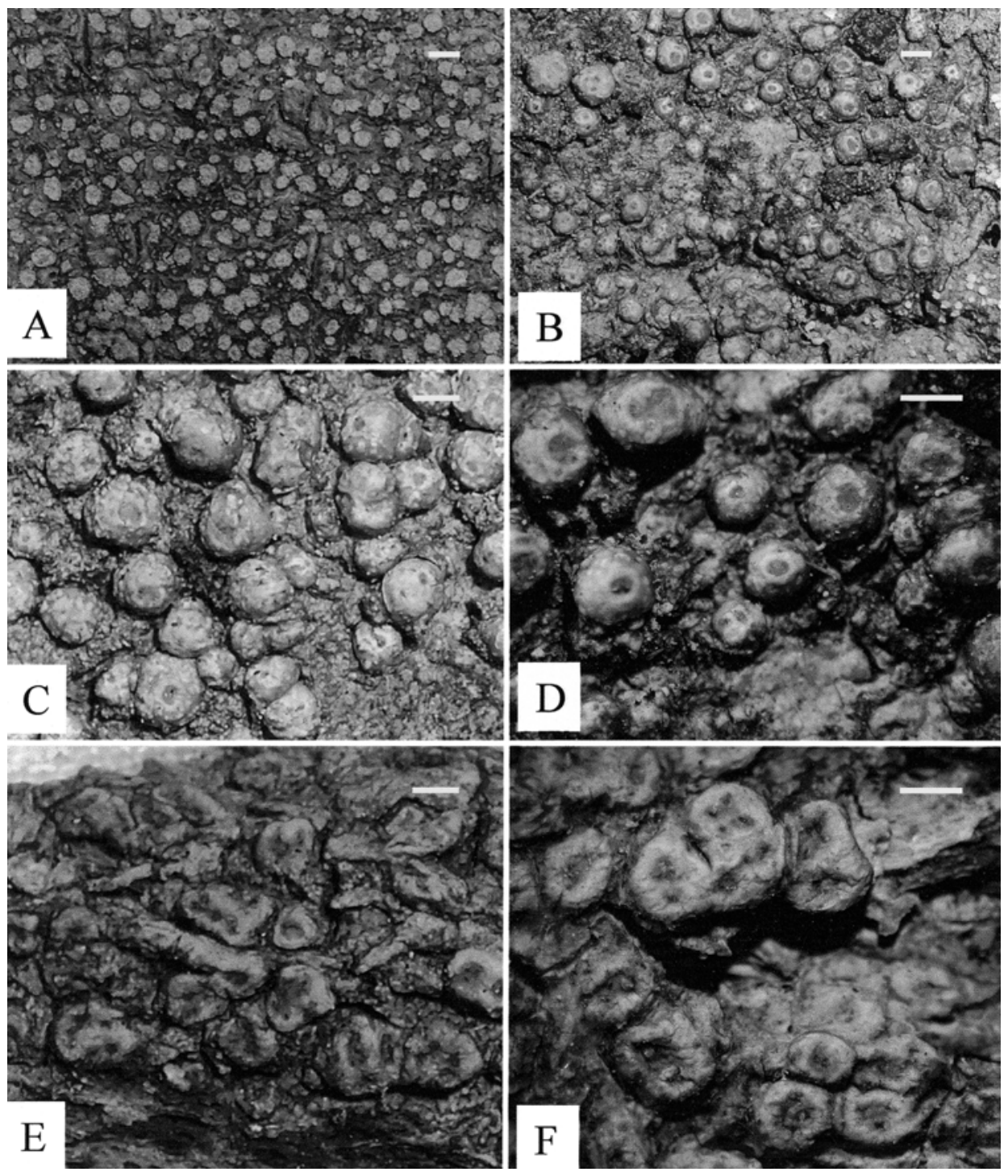

Fig. 8. A. Pertusaria scaberula (Fischer \& Kunsmann s.n., KOBL); B-D. Pertusaria subplanaica (Lambinon 71/1228, LG); E-F. Pertusaria subrigida (Lambinon 72/943-2, LG). Scale = $1 \mathrm{~mm}$.

Pertusaria subrigida Müll.Arg., Bull. Herb. Boissier 3: 636. 1895. Fig. 8, E-F Pertusaria subrigida has apothecia included in rather flattened verrucae, eight, biseriate ascospores, (70-)80-90 × 30-36 $\mu \mathrm{m}$ (measured in the African collection mentioned below) and lacks secondary metabolites. A complete description is provided 
by Archer (1997: 146-147). It is similar to P. rigida which typically produces 4.5-dichlorolichexanthone.

Pertusaria subrigida occurs in Australia/Queensland and New South Wales, and Brazil. It is new for Africa where it has been found in a slightly disturbed montane forest at $2730 \mathrm{~m}$ elevation.

Specimen examined: Rwanda. Parc National de la forêt de Nyungwe, crête du Mt. Muzimu, forêt basse du sommet, J.Lambinon 72/943-2 (LG).

Pertusaria tropica Vain., Catal. Welw. Afr. Pl. 2: 404. 1901.

Fig. 9, A-B

Pertusaria tropica is characterized by disciform apothecia, asci with a single ascospore and the production of hypothamnolic acid. Other lichen compounds detected in the African material cited below are 1'-methyl hypothamnolate (detected in one collection), decarboxyhypothamnolic acid, lichexanthone, protolichesterinic acid, isonephrosterinic acid, and nephrosterinic acid (the latter five minor or absent). See further comments under $P$. commutata. A detailed description is available in Archer (1997: 211-213).

Pertusaria tropica is a widely distributed tropical to subtropical species which has been found in Angola, Zambia [Northern Rhodesia] (Dodge 1964), Thailand, Indonesia/Java, Papua New Guinea and Australia/Queensland (Archer 1997). In the study area, it is rather common and has been found in montane forests (2200-2700 m), in savanas at lower elevation $(1400 \mathrm{~m})$ as well as in plantations at $1750 \mathrm{~m}$. It has been collected once on rocks.

Selected SPEcimens EXAmined: Burundi. Mt. Ngoma, Teza, forêt de montagne, M.Reekmans 5049 (LG). KenYa. Mt. Kenya, Chogoria Forest Reserve, Oct 2001, D.Killmann \& E.Fischer (KOBL); ibid. Chogoria trail, about $8 \mathrm{~km}$ from Chogoria gate, Oct 2002, D.Killmann \& E.Fischer (KOBL). Rwanda. Butare, Station INRS, Callistemon plantation, M.Reekmans 4669 (LG); ibid., Oct 1999, E.Fischer (KOBL); ibid., Mar 2005, E.Sérusiaux (LG). Nyungwe National Park, Rwasenkoko, Oct 1999, E.Fischer (KOBL); ibid., Mar and Oct 2003, D.Killmann \& E.Fischer (KOBL). W Kitabi, secondary forest, Oct 2000, E.Fischer \& K.Kunsmann (KOBL). Km 2.5 de la piste Pindura-Bweyeye, J.Lambinon 74/988 (LG). Akagera National Park, dry forest SW Lake Ihema, Oct 2003, E.Fischer (KOBL).

Pertusaria valliculata Dibben, The chemosystematics of the lichen genus Pertusaria in North America north of Mexico: 117. 1980.

Fig. 9, C

Pertusaria valliculata has been described by Dibben (1980: 117) and is characterized by verruciform apothecia, asci with 4 ascospores and the production of lichexanthone only. The only African specimen cited below agrees with the description, including the chemistry.

Previously Pertusaria valliculata was considered endemic to the United States (OzarkAppalachian region) and this is the first report outside this range. It has been collected once on trees in a montane forest at $2050 \mathrm{~m}$ elevation. Unfortunately, the only known African locality, the Gishwati Forest, was nearly completely destroyed in the nineties.

SPECIMEN EXAMINED: Rwanda, Forêt de Gishwati, km 30 de la route Gisenyi-Kibuye, J.Lambinon 72/ 488 (LG). 
= Pertusaria kahuziensis Dodge, Beih. Nova Hedwigia 12: 258. 1964.

TYPe: Congo (RDC). Km 30, route Kahusi, Nov. 1946, F.L.Hendrickx 4330 (FH-holotype !).

Pertusaria velata is easily distinguished by its disciform apothecia, single-spored asci and the production of lecanoric acid. See further comments under $P$. commutata. A detailed description is available in Dibben (1980: 76-78) \& Archer (1997: 216218).

The type collection of $P$. kahuziensis Dodge is typical of this species, including the chemistry. The list of synonyms for $P$. velata is quite extensive and has been reviewed by Archer \& Messuti (1997) and Messuti (2005); it includes Pertusaria commutans Vain. and P. subvelatula Vain., both described from South Africa (Vainio 1926: 3-4).

Pertusaria velata is a widely distributed species found in all continents except Antarctica (Archer \& Messuti 1997). It grows on bark in tropical, subtropical and temperate areas (in Europe as far north as S Sweden). In the area of study, it has been found in montane forests between 1900-2950 m, as well as in disturbed or cultivated areas.

Additional specimens examined: Rwanda. Forêt de Gishwati, Gikunku, Oct 1991, E.Fischer (KOBL). Parc National de la Forêt de Nyungwe, km 107 de la route Butare-Cyangugu, J.Lambinon 74/847 (LG); Km 2.5 de la piste Pindura-Bweyeye, J.Lambinon 74/987 (LG). Mt. Bigugu, summit, Oct 2003, E.Fischer (KOBL). Gisakura, near tea plantation, Oct 2000, E. Fischer \& K.Kunsmann (KOBL).

Pertusaria verruculifera Vain., Acta Soc. Faun. Fl. Fenn. 7: 110. 1890. Fig. 9, F

Pertusaria verruculifera is a corticolous species characterized by subconical, hemispherical to distinctly flattened, sometimes confluent verrucae with a single (rarely two) rather inconspicuous ostiole, eight, uniseriate ascospores, and the presence of lichexanthone, stictic (major), constictic acids, 2,2'-di- $O$ methylstenosporic (major) and 2'-O-methylperlatolic acids. It has been described from Brazil (Archer 1997: 160-162) and is also known from Argentina and Australia (Queensland). The specimens from Africa differ in containing 2'-Omethylstenosporic acid (the mono-methyl derivative of stenosporic acid) rather than the di-O-methyl derivate found in South American and Australian material. We do not think that this variation is taxonomically significant. Traces of further compounds belonging to the stictic acid complex have been detected in trace in the African material: cryptostitic and menegazziaic acids; in one specimen, the stictic acid chemosyndrome was absent.

Pertusaria verrucculifera is reported here for the first time from Africa. In the Albertine Rift, it is widespread and occurs in montane forest, as well as on introduced tree species at lower elevation (down to $1700 \mathrm{~m}$ ) in disturbed areas.

SELECTED SPECIMENS EXAMINED: BurUndi. Kisozi, plantations forestières de l'ISABU, J.Lambinon 74/1440 (LG). Congo (RDC). Kivu, massif du Kahuzi, piste du Kahuzi, versant SW du Mt. Kahuzi, J.Lambinon 71/1360 (LG). Bordure du marais Musisi, J.Lambinon 71/1143b-2 (LG). Kenya. Mt. Kenya, Chogoria trail, Oct 2002, D.Killmann \& E.Fischer (KOBL). Ibid., Chogoria 

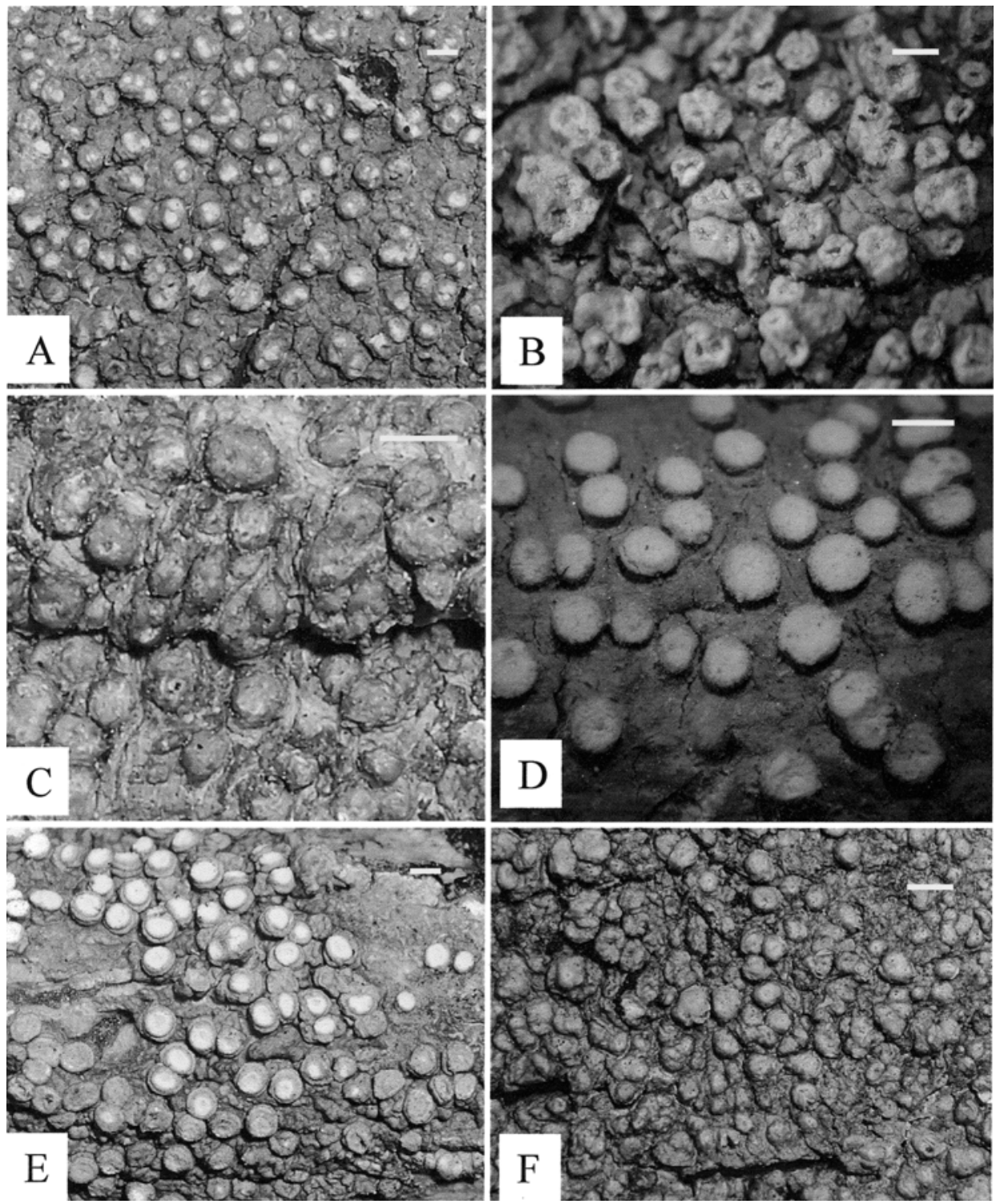

Fig. 9. A-B. Pertusaria tropica (A. Fischer s.n., KOBL, B. Lambinon 72/1069, LG); C. Pertusaria valliculata (Lambinon 72/488, LG); D-E. Pertusaria velata (D. Lambinon 74/987, LG, E. Fischer \& Kunsmann s.n., KOBL); F. Pertusaria verruculifera (Fischer s.n., KOBL). Scale $=1 \mathrm{~mm}$.

gate, Oct 2001, D.Killmann \& E.Fischer (KOBL). RwandA. Rive droite de la Mukungwa un peu en aval des chutes de Rwaza, J.Lambinon 72/859 (LG). Butare, agroforestry fields of PASI project, Oct 2000, E.Fischer \& K.Kunsmann (KOBL). Nyungwe National Park, W Kitabi, Oct 2000, E.Fischer \& K.Kunsmann (KOBL). Ibid., secondary forest at Gisakura tea factory, Oct 2003, E.Fischer (KOBL). 
Pertusaria kigomensis Dodge, Beih. Nova Hedwigia 12: 259. 1964.

Type: Tanzania, W Tanganyika, Kigoma distr., Kungwe-Mahali Peninsula, Kungwe Mts., 5000$8000 \mathrm{ft}$ [525-2440 m in Dodge original description!], over bryophytes on trees in mist forest, Sept 1959, R.M.Haley (BM-holotype!; FH-isotype!).

Chemistry (determined by HPLC): 2'-O-methylperlatolic acid (major) and an unknown fatty acid (trace).

Pertusaria kigomensis has been described from Tanzania in the southern parts of the Albertine Rift, a lichenologically virtually unknown area, and is known only from the type collection. The material obtained from BM is considered to be the holotype as the original publication (Dodge 1964: 259) states "R.M.Haley [the collector] at Kew" [the Kew lichen collections are now housed permanently at BM]. It is a typically isidiate Pertusaria, with conspicuous verrucae containing 1-4 apothecia (each with its own, blackish ostiole), ascospores 8/ascus [not 4(-5) as reported by Dodge], uniseriate or almost so, smooth, 85-102(-112) × 30-37 $\mu \mathrm{m}$.

\section{Pertusaria regenerans Dodge, Beih. Nova Hedwigia 12: 262.1964.}

TyPE: Zambia, E prov., Lundazi-Mzimba, 1200 m, on Ochthocosmos, 18 Oct 1958, N.K.F.Robson $147 \mathrm{~F}$ p. p. (FH-holotype!).

CHEMISTRY (determined by HPLC): haemathamnolic acid (major), picrolichenic acid (major), decarboxyhaemathamnolic acid (trace), atranorin (minor), chloroatranorin (trace).

The only collection is scanty and resembles $P$. commutata, but picrolichenic acid has been detected as a major compound. A section through an apothecium showed only immature asci (4 ascospores per asci were mentioned in the original description). Further material from Zambia is needed to assess the precise identity of this material.

Pertusaria rhodesica Vain., Ann. Univ. Fenn. Abo., ser. A, II, 2: 5. 1926.

TYPE: Zimbabwe, in rupe granitica ad Matoppos in Rhodesia, v. d. Bijl $155 »$ (TUR-Vainio-holotype!). Chemistry: (determined by TLC): lichexanthone (minor), stictic acid (major), constictic acid (minor) and cryptostictic acid (trace).

The type material has been examined and it has 4 ascospores/ascus, 70-85 $\times 35-42 \mu \mathrm{m}$. It does not contain haemathamnolic acid as reported by Harper \& Letcher (1967). So far this species is only known from the type collection.

\section{Pertusaria robsonii Dodge, Beih. Nova Hedwigia 12: 263. 1964.}

TYPE: Zambia, E prov., 7 mi E of Katete, 1100 m, on dead Brachystegia, 8 Oct 1958, N.K.B.Robson (FH-holotype).

Chemistry (determined by HPLC): 2-chlorolichexanthone (major), stictic acid (minor), constictic acid (minor) and lichexanthone (minor).

The only collection is rather well-developed, with pale grey thallus and verruciform apothecia with a single, conspicuous, raised, pale brown ostiole; asci with 8 , biseriate, ascospores, $58-68 \times 28-30 \mu \mathrm{m}$ with a slightly rugulose inner wall. It is identical 
with Pertusaria limbata Vain., known from Brazil, Mozambique and South Africa, and Australia (Archer 1997: 93-95); thus $P$. robsonii is reduced into synonymy with $P$. limbata. A further synonym of $P$. limbata is Pertusaria spaniostoma Vain., described from South Africa (Vainio 1926: 5, Archer 1997: 93).

Vainio (1926: 3-6) has described six new species from southern Africa: Pertusaria subvelatula and $P$. commutans (synonyms of $P$. velata; see above), $P$. dispersa and P. multiplicans (synonyms of P. thiospoda Knight; see Archer 1997: 151), and P. rhodesica.

\section{Key to African Pertusaria found in the area of study}

1 Thallus with isidia or soralia; apothecia usually absent.

Group A

Thallus with apothecia.

2 Apothecia verruciform.

Group B

2 Apothecia disciform. Group C

\section{Group A}

1 Thallus isidiate; 4,5-dichlorolichexanthone and 2'-O-methylperlatolic acid present. P. pilosula

1 Thallus sorediate.

2 Haemathamnolic acid present; saxicolous species.

P. kinigiensis

2 Haemathamnolic absent; corticolous species.

3 Thiophaninic acid present

P. maritima

3 Thiophaninic acid absent. 4

4 Thamnolic acid present.

P. scaberula

4 Thamnolic acid absent.

5 Lichexanthone and stictic acid present.

P. fosseyae

5 Lichesterinic or protolichesterinic acid present.

P. krogiae

\section{Group B}

1 Ascospores 4 per ascus......

1 Ascospores 8 per ascus.

2 Ascospores rough-walled; 2'-O-methylperlatolic acid, confluentic acid and 4,5-dichlorolichexanthone present.

2 Ascospores smooth; lichexanthone present P. microstoma

3 Xanthones absent. P. valliculata

3 Xanthones present 4

4 No lichen compounds produced. P. subrigida

4 Norstictic acid always present, sometimes with 2'- $O$-methylstenosporic acid P. endoxantha

5 Lichexanthone present.. 6

5 Chloroxanthones present. 7

6 Planaic, 2'-O-methylperlatolic and protocetraric acid present

6 2'-O-Methylstenosporic, 2'-O-methylperlatolic and stictic acids present P. lambinonii

7 Thiophaninic and stictic acids present, sometimes with trace of 2-chloro-6- $O$-methylnorlichexan$P$. verruculifera thone.

7 Thiophaninic acid absent. P. leioplacella 8 
8 2-Chlorolichexanthone and divaricatic acid present

8 2-Chlorolichexanthone and divaricatic acid absent; 4,5-dichlorolichexanthone present.

9 Depsides and depsidones absent (except trace of atranorin) P. rigida

9 Depsides or depsidones present.

10 Stictic acid (and related compounds) present, depsides absent. P. melanostoma

10 Stictic acid absent, depsides present.

112,2 -Di- $O$-methylstenosporic acid present. P. subplanaica

11 2'-O-Methylperlatolic acid present. P. mesotropa

\section{Group C}

12 Lecanoric acid present P. velata

12 Lecanoric acid absent. 2

13 Hypothamnolic acid present..... P. tropica

13 Haemathamnolic acid present P. commutata

\section{Acknowledgements}

The authors are indebted to J.Lambinon for his comments during the preparation of this paper and for making his collections from the Albertine Rift available to us. One of us (AWA) is grateful to the National Herbarium of New South Wales for arranging the loan of specimens and for permission to use the facilities of the Herbarium. Three of us (EF, DK and ES) warmly thank the Institut de Recherche Scientifique et Technologique (IRST) in Butare and the Bureau de Jumelage Rhenanie Palatinat - Rwanda for logistical support during the field trips. They are grateful to the Office Rwandais du Tourisme et des Parcs Nationaux (ORTPN) for collection and export permits. The studies in Kakamega Forest and Mt. Kenya by DK and EF were supported within BIOTA-EAST E04 (LC0625C1) by the BMBF (German Ministry of Education and Research). Special thanks go to the East African Herbarium (EA), the National Museums of Kenya, (NMK), and to Kenya Wildlife Service (KWS) for research and collection permits.

\section{References}

ARCHER, A.W. (1997): The lichen genus Pertusaria in Australia. - Bibl. Lichenol. 69: 1-249.

ARCHER, A.W. \& J.A. ELIX (1992): Further new species and new reports of Perusaria (lichenised Ascomycotina) from Australia. - Mycotaxon 45: 417-431.

ARCHER, A.W. \& J.A. ELIX (1998a): Additional new species and two new reports in the lichen genus Pertusaria (lichenised Ascomycotina) from Papua New Guinea. - Mycotaxon 67: 155-179.

ARCHER, A.W. \& J.A. ELIX (1998b): The lichen genus Pertusaria (Lichenised Ascomycotina) in Papua New Guinea: three new species and two new reports. - Mycotaxon 69: 311-318.

ARCHER, A.W. \& M.I. MESSUTI (1997): Pertusaria velata (Turner) Nyl. and its synonyms. Mycotaxon 61: 375-379.

ARCHER, A.W., J.A. ELIX \& H. STREIMANN (1995): The lichen genus Pertusaria (Lichenised Ascomycotina) in Papua New Guinea. - Mycotaxon 56: 387-401.

DIBBEN, M.J. (1980): The chemosystematics of the lichen genus Pertusaria in North America north of Mexico. - Milwaukee Publ. Biol. Geol. 5: 1-162.

DODGE, C.W. (1964): Some lichens of tropical Africa. IV. Dermatocarpaceae to Pertusariaceae. Beih. Nova Hedwigia 12: 1-282. 
ELIX, J.A., A. APTROOT \& A.W. ARCHER (1997): The lichen genus Pertusaria (lichenised Ascomycotina) in Papua New Guinea and Australia: twelve new species and thirteen new reports. Mycotaxon 64: 17-35.

ELIX, J.A., M. GIRALT \& J.H. WARDLAW (2003): New chloro-depsides from the lichen Dimelaena radiata. - Bibl. Lichenol. 86: 1-7.

HARPER, S.H. \& R.M. LETCHER (1967): Chemistry of lichen constituents. Part III. Haemathamnolic acid: a new $\beta$-orcinol depside from Pertusaria rhodesiaca Vainio. - J. Chem. Soc. 17C: $1603-1608$.

JARIANGPRASERT, S. (2006): New taxa of the lichen genus Pertusaria (Ascomycota) from Thailand. - Mycotaxon 96: 109-121.

LUMBSCH, H.T. (2002): Analysis of phenolic products in lichens for identification and taxonomy. - In: KRANNER, I., R.P. BECKETT \& A.K. VARMA (eds.): Protocols in Lichenology. Culturing, Biochemistry, Ecophysiology and Use in Biomonitoring. Springer-Verlag, Berlin, Heidelberg, pp. 281-295.

LUMBSCH, H.T., H.T. NASH \& M.I. MESSUTI (1999): A revision of Pertusaria species with hyaline ascospores in southwestern North America (Pertusariales, Ascomycotina). - Bryologist 102: 215-239.

LUMBSCH, H.T. \& H.T. NASH (2002): Pertusaria. - In: NASH, H.T., B.D. RYAN, C. GRIES \& F. BUNGARTZ (eds.). Lichen Flora of the Greater Sonoran Desert Region. Vol. I: 341-357.

MESSUTI, M.I. (2005): The genus Pertusaria (Pertusariales: Pertusariaceae) in the Juan Fernández Archipelago (Chile). - Lichenologist 37: 111-122.

MESSUTI, M.I., U. BECKER \& A.W. ARCHER (2007): New or interesting saxicolous Pertusaria species (Pertusariales: Pertusariaceae) from Zimbabwe. - Lichenologist 39: 227-230.

MÜLLER (ARGOVIENSIS), J. (1889): Lichenes Sebastianopolitani lecti a CL Dr. Glaziou et a Dr. J. Mueller elaborati. - Nuovo Giorn. Bot. Ital. 21: 353-364.

ORANGE, A., P.W. JAMES \& F.J. WHITE (2001): Microchemical methods for the identification of lichens. - British Lichen Society. $101 \mathrm{pp}$.

SCHMITT, I., Y. YAMAMOTO \& H.T. LUMBSCH (2006): Phylogeny of Pertusariales (Ascomycotina): resurrection of Ochrolechiaceae and new circumscription of Megasporaceae. - J. Hattori Bot. Lab. 100: 753-764.

SWINSCOW, T.D.V. \& H. KROG (1988): Macrolichens of East Africa. - British Museum (Natural History), London, $390 \mathrm{pp}$.

VAINIO, E.A. (1926): Lichenes Africae Novi. - Ann. Univ. Fenn. Abo., ser. A., II: 1-33.

Received 13 August 2008, accepted in revised version 22 September 2008. 